Journal of Teacher Education for Sustainability, vol. 21, no. 1, pp. 88-102, 2019

\title{
Pro-ecological Views of Kosovar Teachers Measured by Endorsement of the New Ecological Paradigm Statements
}

\author{
Veselaj Zeqir, Mustafa Behxhet, and Krasniqi Zenel \\ University of Prishtina, Prishtina, Republic of Kosovo
}

\begin{abstract}
The New Ecological Paradigm (NEP) scale is a survey-based metric devised to measure the environmental concerns of groups of people through using a standard survey instrument. This is the first research to measure how in-service teachers perceive the NEP scale in Kosovo. The aim of the current study was to assess the concerns of teachers in Kosovo about environment in the age of Anthropocene by supporting anthropocentric or eco-centric views through using NEP scale as a standardized instrument. Thus, the research was an attempt to investigate how teachers perceived changes in the environment and how much they agreed with the $15 \mathrm{NEP}$ statements. This study followed a quantitative methodology, employing a questionnaire to secure socio-economic data about the teachers, the information sources that they used for environmental information, their perceptions about changes in the environment in the past decade, expectations for the next decade, and the support of the NEP's statements. A total number of 88 primary school teachers (teaching grades 1-5) participated in this study who came from three most populated regions of Kosovo. The teachers responded to the questionnaire based on their teaching experience, sources of environmental information which they used, their perceptions and expectations in the environmental changes, and their attitudes toward the NEP statements. The results of the research showed that teachers' concerns about environmental developments were mostly consistent with the views of the NEP scale or pro-ecological worldviews. The survey results provided a positive indication that Kosovar teachers sought to offer a new eco-centric worldview for the next generation, instead of the anthropocentric one in which they had been living.
\end{abstract}

Keywords: anthropocentrism, eco-centrism, dimensions, paradigm, statements.

\section{Introduction}

Nature and people have had a permanent interdependent relationship from earliest human origins. However, the relationship between humankind and the rest of nature has for centuries been central to the debate over management of natural resources. Is humanity created to rule over nature or only to be a part of the natural world? Are natural resources finite or infinite? These are among the many ecological questions 
generating discussions and societal concerns in the past. Fedosejeva et al. (2018) pointed out that in spite of many global initiatives and local activities launched on the implementation of the idea of sustainable development, the $21^{\text {st }}$ century was claimed to be the phenomenon of the Anthropocene age, which became a reality that had to be recognized not just in science where the phenomenon had already been known (Kress \& Stine, 2017; Millett, 2015). The phenomenon of Anthropocene has been gradually revealed and become a phenomenon that demonstrates the unsustainable quality of the ecological, cultural, and social relationship of a human being. This situation has already acquired the name of the Anthropocene era in recent years (Figueroa, 2017).

It is important for the development of responsible environmental management (LaTrobe \& Acott, 2000) that there is an understanding of people's attitudes and value systems about the environment. Especially, since the 1970s (Erdogan, 2009), people all over the world have increasingly witnessed industrial and nuclear accidents, oil spills, mismanagement of solid and hazardous waste, depletion of resources, environmental deterioration, global warming and climate change, environmentally induced diseases and other environmental problems. With mounting awareness of environmental problems, one can recognize that humans are not immune to ecological constraints and the future generations and ecosystems are in jeopardy (Cordano, Welcomer, \& Scherer, 2003; Vlek \& Steg, 2007). This jeopardy asks for understanding of two core issues. First, there is the need to understand the linkage of industrial production, distribution of goods and consumption. Second, there is the need to connect these environmental issues with the belief systems and values that underlie these problems (Dunlap \& van Liere, 1978). Nevertheless, many environmental problems stem from the widespread anthropocentric world view prevalent in the past. According to such an anthropocentric view, humans are the superior nature; there is abundance of natural resources and there is no need for conservation; human beings, by virtue of possessing culture and technology, are able to adapt nature to human ends, rather than adapt to the natural environment. Based on this view, social sciences often treated humans as they were exempt from ecological constraints (Dunlap, 1980). These views have been manifested in a set of beliefs and values called the "Dominant Social Paradigm" (DSP). DSP embraces a belief in limitless resources of the planet, continuous progress of society and the necessity of economic growth. Moreover, it emphasizes faith in the problem-solving abilities of science and technology and strong emotional commitment to a laissez-faire economy and to sanctity of private property rights (Albrecht, Bultena, Hoiberg, \& Novak, 1982).

A shift from DSP to an eco-centric "New Environmental Paradigm" (NEP) has emerged with increasing concerns about the environment. The NEP concentrates on beliefs about humans' ability to upset the balance of nature, the existence of limits to growth for human societies and humanity's proper rule over the rest of nature (Dunlap, Van Liere, Mertig, \& Jones, 2000). The NEP worldview is based on six pillars: high valuation of nature; generalized compassion toward other species, other peoples, and other generations; careful planning and acting to avoid risks to both humans and nature; recognition of limits to growth to which humanity must adapt; appeal for creation of a society based on cooperation, openness and participation; and the need for a new form of politics that is consultative, participatory in nature, and emphasizing foresight and planning (Milbrath, 1984). In contrast to anthropocentrism, eco-centrism is characterized by the centrality of ecosystems or the biosphere, varying degrees of egalitarianism between species and valuing the non-human species, ecosystems and life itself regardless of its 
use-value for us (Kortetmäki, 2013). Eco-centrism is synonym of pro-ecological attitudes of the peoples.

The NEP scale, sometimes referred to as the revised NEP, is a survey-based metric devised by the US environmental sociologist Riley Dunlap and his colleagues. It measures the environmental concerns of groups of people through employing a standard survey instrument. The original NEP had 12 environmental items (statements) that could be scaled on the basis of how populations responded to them. The original NEP was criticized for several shortcomings, including a lack of internal consistency among individual responses, poor correlation between the scale and behavior, and "dated" language used in the instrument's statements. Dunlap and his colleagues, then, developed the NEP scale to respond to criticisms of the original NEP scale. This is sometimes referred to as the revised NEP scale to differentiate it from the original NEP scale.

Dunlap and van Liere (1978) argue that their NEP scale is reliable, valid, and onedimensional. Contrary to Dunlap and van Liere (1978), researchers such as Gooch (1995), Bechtel, Corral-Verdugo, Asai, and Riesie (1999) and Nooney, Woodrum, Hoban, and Clifford (2003) identified two dimensions within the NEP scale. Moreover, Manoli, Johnson, and Dunlap (2007) identified three dimensions. Besides, LaTrobe and Acott (2000) identified four dimensions within NEP scale. Furthermore, Lück (2003) identified five dimensions in the NEP scale: anti-anthropocentrism (AA), anti-exclusion (AE), balance of nature (BN), ecological crisis (EC) and limits to growth (LG). The multidimensional nature of the NEP scale suggests that measuring environmental attitudes may be more complex than was originally thought. Researchers suggest that there is not enough evidence for a fixed number of dimensions, and further research in that area is recommended (Lalonde \& Jackson, 2002).

The revised NEP scale is constructed based on 15 statements. Respondents are asked to indicate the strength of their agreement or disagreement with each statement. Responses to these 15 statements are, then, used to construct various statistical measures of environmental attitudes and concerns. Studies using the original and revised NEP focused on the selected socio-economic groups of people to provide information on the nature of environmental worldviews. Researchers such Johnson, Bowker, and Cordell (2004), Poortinga, Steg, and Vlek (2004), and Noblet, Anderson, and Teisl (2013) conducted cross-sectional analyses by using various socio-demographic, cultural, attitudinal, and behavioral variables. Other researchers used NEP to highlight attitudes toward specific environmentally relevant matters, such as the national parks (Noe \& Snow 1990), nature based tourism (Luzar, Diagne, \& Henning, 1995), etc. Moreover, Bechtel et al. (2006), Leung and Rice (2002), and Petegem and Blieck (2006) were interested in using the NEP scale in cross-national or cross-cultural comparisons. Some researchers worked with a single selected population such as university students (Rideout et al., 2005; Harraway et al., 2012), teacher students (Aydos \& Yagci, 2015), pre-service science teachers (Ozsoy, 2012) and they tried to test the scale and determine the nature of the general distribution. In Kosovo, Veselaj and Torkar (2016) compared environmental worldviews about sustainable development and climate changes between science non-major and major teacher students. Furthermore, Lindemann-Mathies and Hyseni (2009) evaluated knowledge and perceptions of the stakeholders and laypersons about biodiversity issues.

In Kosovo, DSP and NEP are new concepts and no research until now has sought to address these topics. There are no studies assessing attitudes regarding DSP or the 
original and revised NEP. The Republic of Kosovo, once part of the Socialist Federal Republic of Yugoslavia, underwent a bloody war in 1998-99, part of the wider wars of Yugoslav secession. After the war, the country was a territory under UN interim administration, with significant international community support in post-conflict reconciliation. The country of 1.8 million people declared its independence on 17 February 2008. Environmental problems in Kosovo had accumulated over the last three decades as the consequences of the uncontrolled use of natural resources, the industry growth, and the almost entirely coal-based energy production with high pollution, with lack of appropriate environmental policies, laws, and institutions to address these problems (Veselaj, 2013). Some of the main factors that exacerbate the current environmental situation are as follows: $97 \%$ of the country's energy is based on lignite coal; lack of waste-water treatment; very poor waste management amidst unplanned and uncontrolled urbanization; and a weak road transport system with very old diesel cars and poor road infrastructure. As a result, the environment in Kosovo has been degraded with severe negative impact on public health. This situation is partly due to a DSP approach and anthropocentric thinking which has characterized the country's economic and social development in recent decades. The public's awareness about environmental problems and environmental education is still limited (Veselaj \& Torkar, 2016). While facing many environmental burdens, Kosovo possesses a rich natural environment, and the value it places on biodiversity can be a motivating factor contributing toward potential acceptance of the NEP values. At present there are 116 protected areas covering 118,913 hectares, $10.9 \%$ of the territory of the Republic of Kosovo (Veselaj \& Mustafa, 2015).

The education system in Kosovo includes pre-school education (children aged 1-5) and a pre-primary grade for children (ages 5-6). Formal pre-university education (ages 6-18) comprises primary (grades 1-5), lower secondary school (grades 6-9) and upper secondary (grades 10-12) levels. In 2011, a new Curriculum framework was adopted; and one year later, three core curricula for each of the educational level were adopted (Veselaj \& Krasniqi, 2014).

\section{Method}

The participants of the survey consisted of teachers who took part in the training on the use of "Green Pack Junior," an environmental educational kit for students in grades 1-5 intended to promote environmental protection and sustainable development. The participants were selected based on convenience sampling. The sample can be understood as pilot in its nature, considering the overall number of primary education level teachers. Teachers were informed about the survey questionnaire at the beginning of the training course, while participation was an individual choice. From 99 trainees, the survey sample was composed of 88 teachers, of which 82 or $93.2 \%$ were female, and 6 $(6.8 \%)$ were male teachers. These teachers taught all subjects within curricular fields, including environmental content in cross-curricular fields. Three municipalities where respondents live and work have been severely affected by the coal power plants in operation ("Kosovo A" and "Kosovo B"), thus, they are among the most polluted urban areas of Kosovo. The majority of the respondents $(77.2 \%)$ were from the urban areas of Prishtina, Fushe Kosova and Obiliq while $22.8 \%$ were from rural schools. The most frequent age of teachers was 30-39 years old (37.5\%), followed by those aged 40-49 $(31.8 \%), 20-29(19.3 \%)$, and 50-59 years (11.4\%). The working experience of respon- 
dents ranged from less than 5 years to more than 25 years. Overall, $72 \%$ of the responding teachers had 15 years or less of working experience, reflecting the relatively young age of the elementary school teaching staff in the selected municipalities.

During the conduction of this study, we employed a-three-part-questionnaire. The first part contained the socio-economic data of the respondents such as residence (urban or rural), gender, working experience, interest and knowledge of the environmental problems. The second part addressed respondents' perceptions of the changes in the environment in the last 10 years and their environmental expectations over the next 10 years. The third part which was the main part addressed the respondents' compliance with the 15 statements of the new ecological paradigm scale, using the Likert scale (Likert, 1932) ranging from: strongly agree, agree, undecided, disagree and strongly disagree.

\section{Results and Discussion}

One of the aims of the current study was to evaluate the interest of the teachers about the environment in which they live; measuring the level of interest from "very high," "high," "some interest," "small interest" to "not interest at all." The majority of teachers (48) expressed very high interest in the environmental issues, 29 teachers showed high interest, while 11 show some interest. It is worth mentioning that no teacher was uninterested in environmental issues.

The questionnaire also queried the teachers about the sources which they used for securing information and knowledge about the environment and environmental problems (see Fig. 1). Three resources: TV, the internet, and their own schooling were identified as the primary points of access to information about the environment. Figure 1 shows a variety of information resources used by teachers. Of the three sources of environmental information used the most by the teachers, 75 respondents cited TV documentaries, 71 cited the internet sources, and 64 cited their prior education. Teachers rarely used radio (8) and newspapers (11) as information sources.

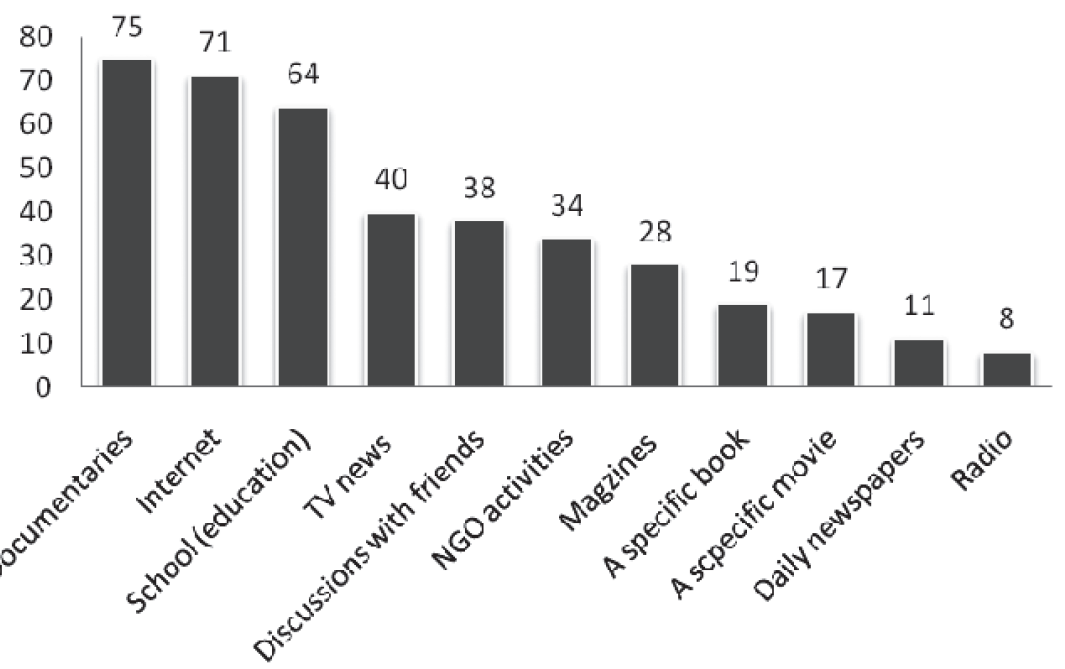

Figure 1. Sources used by teachers for environmental information 
That may be either because the audio and daily newspapers rarely give space to environmental issues in Kosovo, or it may be that respondents rarely listen to the radio or read the daily press.

One of the objectives of the research was to discover how teachers perceive environmental changes in the past decade at the global and Kosovo level (Fig. 2).

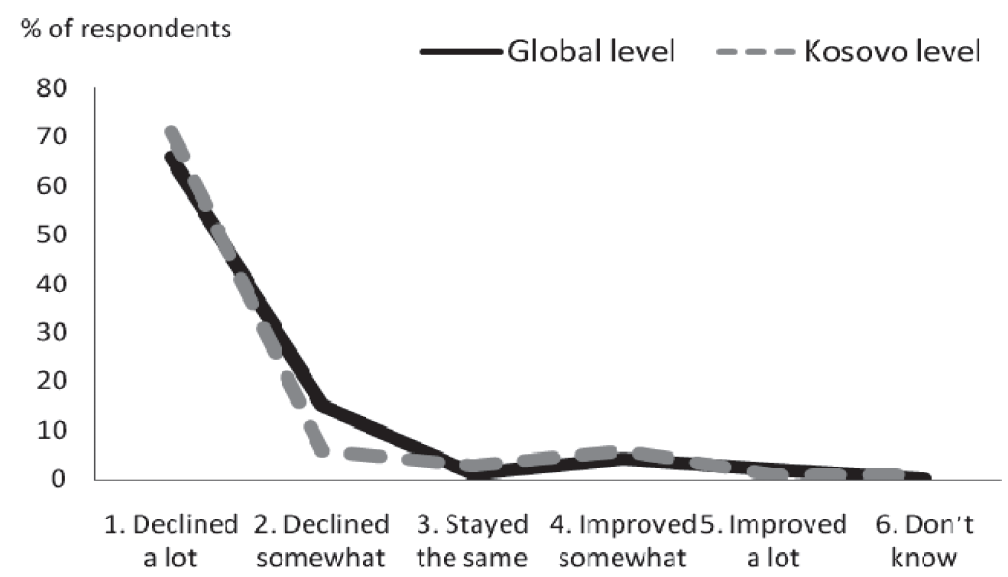

Figure 2. Perceived trend of global and national environmental changes over the past 10 years

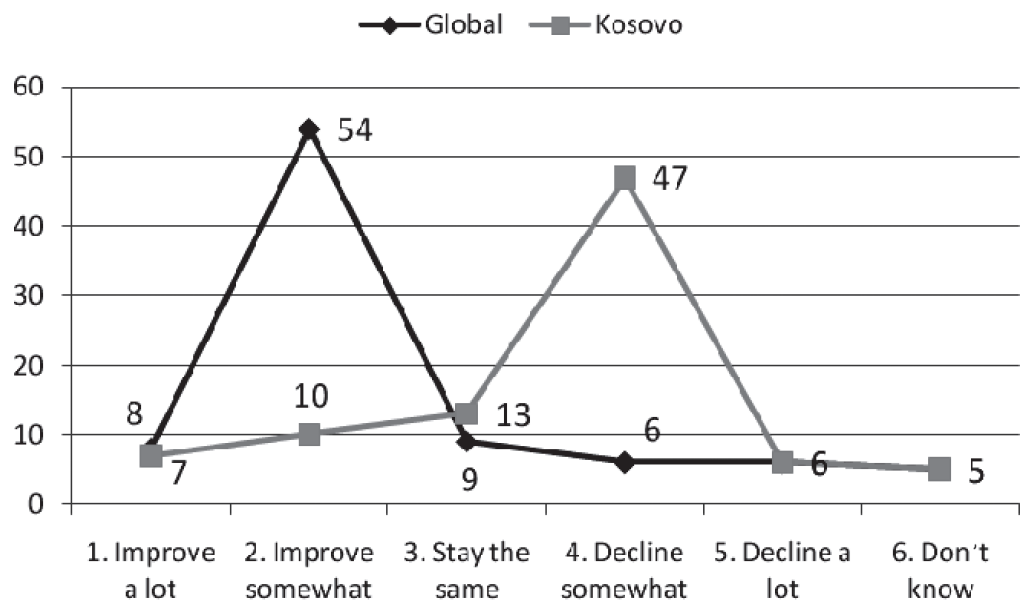

Figure 3. Expectations of the teachers about environmental developments in the next 10 years

The environmental situation in the past decade was generally perceived by the teachers as deteriorating at both the global and country level. Eighty-one respondents $(92 \%)$ labeled the situation as worsening at the global level; $77(87.5 \%)$ also saw deterioration at the country level. Only 6 respondents, or $6.8 \%$, identified improvement in the environmental situation at the global level in the past decade, and only 7 respondents $(7.9 \%)$ saw such an improvement at the country level. Only one teacher evaluated the 
global environmental situation to be unchanged over the past decade, and three found the situation unchanged at the national level.

When respondents were asked to make predictions regarding environmental developments within next decade (Fig. 3), 75\% of them expected improvement of the environmental situation at the global level, $13.6 \%$ expected further deterioration, while $10.2 \%$ saw the environmental situation as unchanging. At the country level, $60.2 \%$ of respondents expected further deterioration of the environment; $19.3 .7 \%$ expected improvement, and $14.8 \%$ saw the situation remaining the same while $5.7 \%$ have no stand.

The core of the survey involved respondent reaction to the revised NEP statements (Table 1). Fifteen statements in this research were divided and analyzed in five distinct categories according to Lück (2003) dimensions of the NEP scale.

Table 1

Agreement of Kosovo Teachers with Items of NEP

\begin{tabular}{|c|c|c|c|c|c|c|}
\hline \multirow[t]{2}{*}{ Statements of New Ecological Paradigm (NEP) } & .0 & 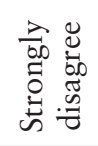 & 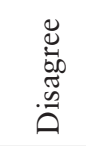 & $\underset{\Xi}{\leftrightarrows}$ & $\underset{\overleftarrow{b}}{\mathbb{Z}}$ & 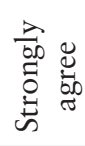 \\
\hline & & $\%$ & $\%$ & $\%$ & $\%$ & $\%$ \\
\hline $\begin{array}{l}\text { 1. We are approaching the limit of the number } \\
\text { of people the earth can support }\end{array}$ & LG & 7.9 & 29.6 & 12.5 & 44.3 & 5.7 \\
\hline $\begin{array}{l}\text { 2. Humans have the right to modify the natural } \\
\text { environment to suit their needs }\end{array}$ & $\mathrm{AA}$ & 20.5 & 34.1 & 1.1 & 27.3 & 17.0 \\
\hline $\begin{array}{l}\text { 3. When humans interfere with nature it often } \\
\text { produces disastrous consequences }\end{array}$ & $\mathrm{BN}$ & 2.3 & 4.6 & 5.7 & 57.9 & 29.5 \\
\hline $\begin{array}{l}\text { 4. Human ingenuity will insure that we do not } \\
\text { make the earth unlivable }\end{array}$ & $\mathrm{AE}$ & 3.4 & 5.7 & 10.2 & 33.0 & 47.7 \\
\hline 5. Humans are severely abusing the environment & $\mathrm{EC}$ & 0 & 5.7 & 1.1 & 55.7 & 37.5 \\
\hline $\begin{array}{l}\text { 6. The earth has plenty of natural resources if } \\
\text { we just learn how to develop them }\end{array}$ & LG & 0 & 1.1 & 2.3 & 53.4 & 43.2 \\
\hline $\begin{array}{l}\text { 7. Plants and animals have as much right as } \\
\text { humans to exist }\end{array}$ & $\mathrm{AA}$ & 1.1 & 1.1 & 0 & 39.8 & 58.0 \\
\hline $\begin{array}{l}\text { 8. The balance of nature is strong enough to } \\
\text { cope with the impacts of modern industries }\end{array}$ & $\mathrm{BN}$ & 10.2 & 51.1 & 15.9 & 15.9 & 6.9 \\
\hline $\begin{array}{l}\text { 9. Despite our special abilities humans are still } \\
\text { subject to the laws of nature }\end{array}$ & $\mathrm{AE}$ & 0 & 20.4 & 13.7 & 54.5 & 11.4 \\
\hline $\begin{array}{l}\text { 10. The so-called "ecological crisis" facing } \\
\text { humankind has been greatly exaggerated }\end{array}$ & $\mathrm{EC}$ & 15.9 & 44.3 & 9.1 & 21.6 & 9.1 \\
\hline $\begin{array}{l}\text { 11. The earth is like a spaceship with very } \\
\text { limited room and resources }\end{array}$ & LG & 3.4 & 19.3 & 18.2 & 48.9 & 10.2 \\
\hline $\begin{array}{l}\text { 12. Humans were meant to rule over the rest } \\
\text { of nature }\end{array}$ & $\mathrm{AA}$ & 1.1 & 30.7 & 15.9 & 46.6 & 5.7 \\
\hline $\begin{array}{l}\text { 13. The balance of nature is very delicate and } \\
\text { easily upset }\end{array}$ & $\mathrm{BN}$ & 1.1 & 9.1 & 5.7 & 59.1 & 25 \\
\hline $\begin{array}{l}\text { 14. Humans will eventually learn enough about } \\
\text { how nature works to be able to control it }\end{array}$ & $\mathrm{AE}$ & 0 & 14.8 & 10.2 & 53.4 & 21.6 \\
\hline $\begin{array}{l}\text { 15. If things continue on their present course, } \\
\text { we will soon experience a major ecological } \\
\text { catastrophe }\end{array}$ & $\mathrm{EC}$ & 1.1 & 6.9 & 9.1 & 44.3 & 38.6 \\
\hline
\end{tabular}


1. Limits to Growth (LG) dimension. NEP statements 1, 6, and 11 address the development and equitable use of resources, as well as the capacity for human intervention in, and exploitation of, nature (Fig. 4). Regarding the concern which we are approaching the Earth's population capacity (Statement 1 ), $50 \%$ of respondents agreed, and $37.5 \%$ disagreed, while $12.5 \%$ were undecided. In response to the statement that the planet has enough resources, but humans have to use them wisely (Item 6), $96.6 \%$ of the respondents agreed, while only $2.3 \%$ disagreed. In response to the view that the Earth is like a spacecraft with limited resources (Item 11), 59.1\% of respondents agreed, $22.7 \%$ disagreed while $18.2 \%$ were undecided. Overall, half of the respondents believed that we are approaching the population and resource capacity of the Earth, almost all respondents believed in enough resources of the Earth under condition of wise use, while majority of them supported the idea of the Earth as spacecraft with limited resources.

$\cdots \bullet \cdot 1$. We are approaching the limit of the number of people the earth can support

$-2-6$. The Earth has plenty of natural resources if we just learn how to develop them

$\longrightarrow 11$. The earth is like a spaceship with very limited room and resources

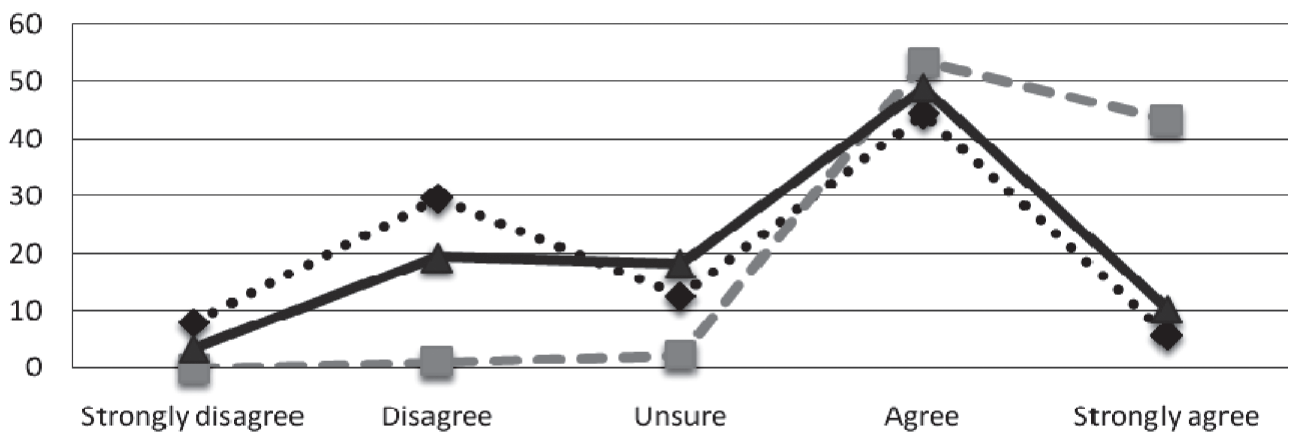

Figure 4. Attitudes of respondents about limit to growth (LG) statements: 1, 6, and 11

2. Anti-Anthropocentrism (AA) dimension. NEP values reject the DSP worldview that nature was primarily created for use by and consumption by humankind (Fig. 5). In response to item 12, that humans are meant to rule the rest of nature, $52.3 \%$ agreed with the statement, $31.8 \%$ disagreed, while $15.9 \%$ of respondents remained undecided. On item 2, that people have the right to adjust nature for their own needs, more than half of respondents $(54.5 \%)$ disagreed, while $44.3 \%$ saw this as acceptable. Almost all respondents $(97.7 \%)$ agreed that plants and animals have as much right to exist as humans (Item 7). Overall, more than half of respondents supported the idea of humans continuing to rule the rest of nature, more than half did not support the idea that humans have the right to modify nature to suit only their own needs. Almost all respondents gave to plants and animals the same right to exist as humans. 
$\cdots \cdots 2$. Humans have the right to modify the natural environment to suit their needs

-2 - Plants and animals have as much right as humans to exist

-12 . Humans were meant to rule over the rest of nature

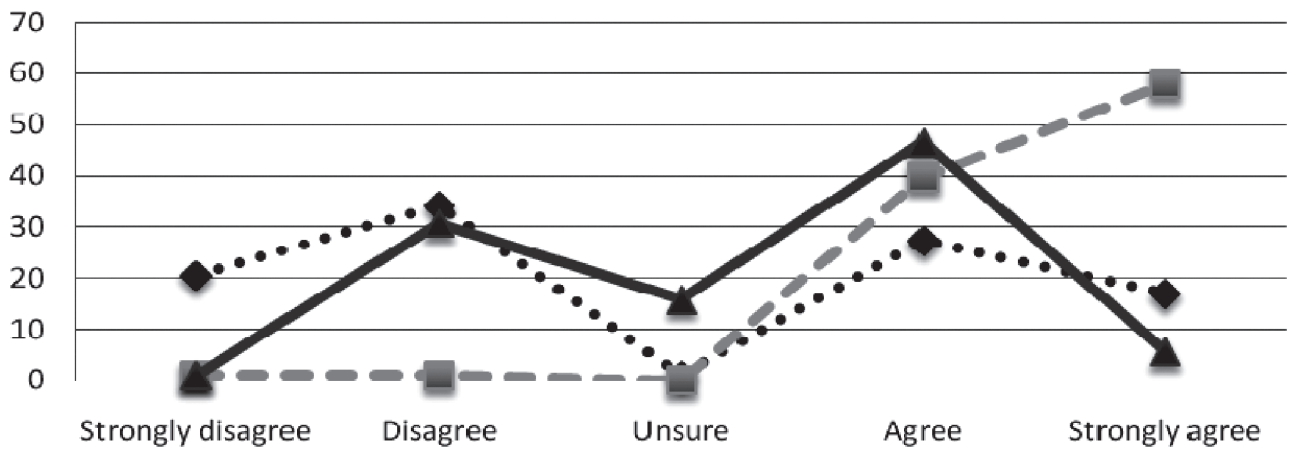

Figure 5. Attitudes of respondents about anti-anthropocentrism dimension (AA) statements: 2,7 , and 12

3. The Balance of Nature (BN) dimension - NEP values express concern that human activities jeopardize the balance of nature (Fig. 6). In response to the statement that human interference with nature often produces disastrous consequences (Item 3), 87.5\% of respondents agreed, 6.8\% were undecided, and 5.7\% disagreed. Regarding item 8 , that the balance of nature is strong enough to cope with the impact of modern industry, the majority of respondents $(61.4 \%)$ disagreed, $22.7 \%$ agreed, and $15.9 \%$ remained undecided. Overall, 3/4 of respondents believed the balance of nature to be very delicate; more than $3 / 4$ were concerned with disastrous consequences of human interference with nature, while more than half of respondents did not believe that the power of nature could counterbalance the impact of modern industry.

... 3. When humans interfere with nature it often produces disastrous consequences

- - -8 . The balance of nature is strong enough to cope with the impacts of modern industries

-13 . The balance of nature is very delicate and easily upset

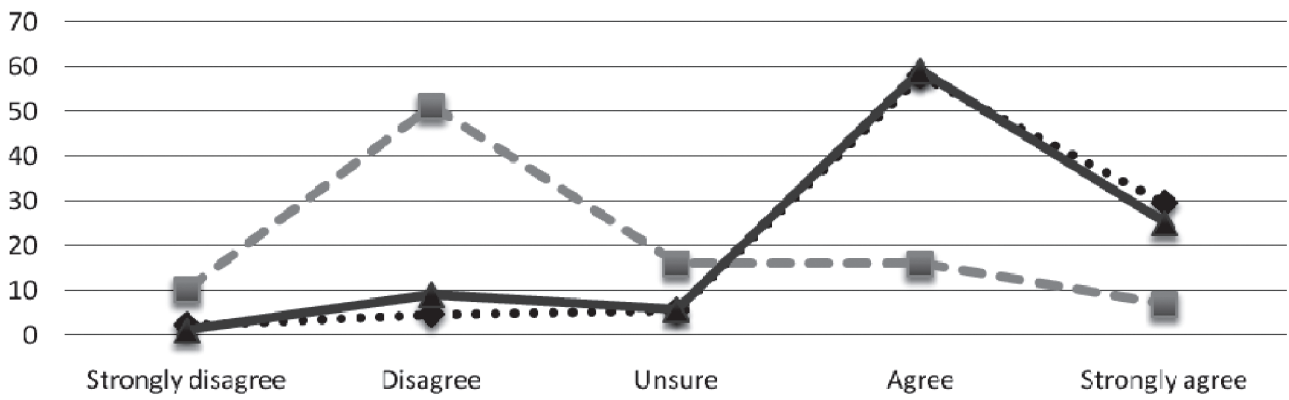

Figure 6. Attitudes of respondents about balance of nature $(\mathrm{BN})$ statements: 3, 8, and 13 
4. Anti-Exclusion (AE) dimension. NEP rejects the value that DSP places on human exclusivity. DSP envisions that humans are not limited by nature. Hence, human systems of control should dominate over natural constraints. By contrast, NEP opposes the exclusivity of humankind vis a vis nature, thus the value of "AntiExclusion" is addressed (Fig. 7). Regarding the statement that human intelligence would assure that the Earth never became uninhabitable (Item 4), 80.7\% of respondents agreed, $10.2 \%$ were undecided, and $9.1 \%$ disagreed. In the case of item 14 , that people would manage to learn how to control nature, $75 \%$ agreed, $10.2 \%$ were undecided on the matter, while $14.8 \%$ disagreed.

$\cdots \bullet 4$. Human ingenuity will insure that we do not make the earth unlivable

- -9 . Despite our special abilities humans are still subject to the laws of nature

- 14. Humans will eventually learn enough about how nature works to be able to control it

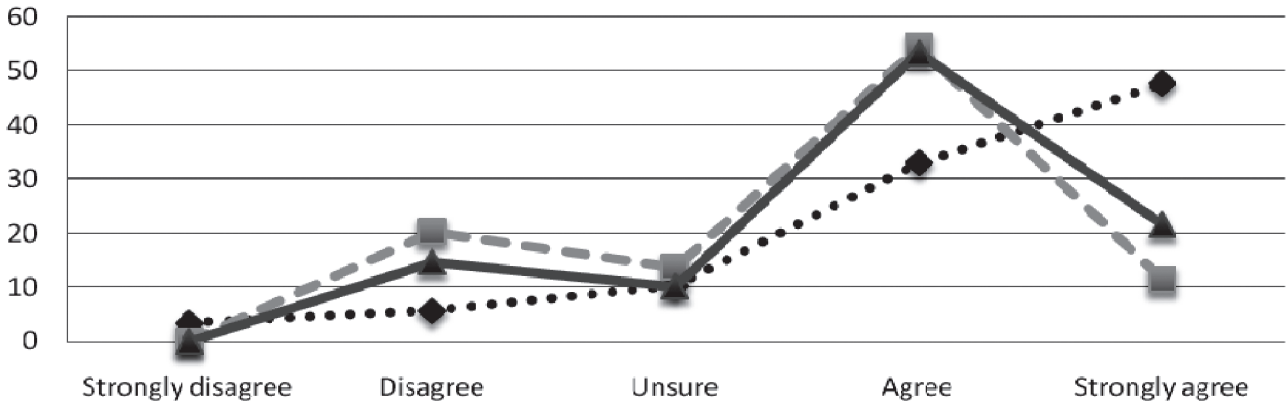

Figure 7. Attitudes of respondents about anti-exclusion dimension (AE) statements: 4, 9 , and 14

Despite the confidence shown by respondents in human ability to control nature in Fig. 5, the same respondents in item 9 indicated that humans, despite their abilities, are still subject to the laws of nature. On item $9,62.5 \%$ agreed that humans are still subject to natural laws, $19.3 \%$ disagreed, and $12.5 \%$ were undecided. Overall, more than $3 / 4$ of respondents believed that, as intelligent beings, humans would avoid making Earth unlivable, $3 / 4$ of them believed that humans would learn enough to control nature, and majority of respondents accepted the proposition that humanity was still subject to the laws of nature.

5. Ecological Crisis (EC) dimension. NEP assumes that humans are abusing the environment, and with potentially disastrous consequences (Fig. 8). In line with this NEP assumption, more than $60 \%$ of respondents disagreed that the "ecological crisis" is being exaggerated (item 10 ), only $22.7 \%$ agreed, and $9.1 \%$ were uncertain about the issue. 


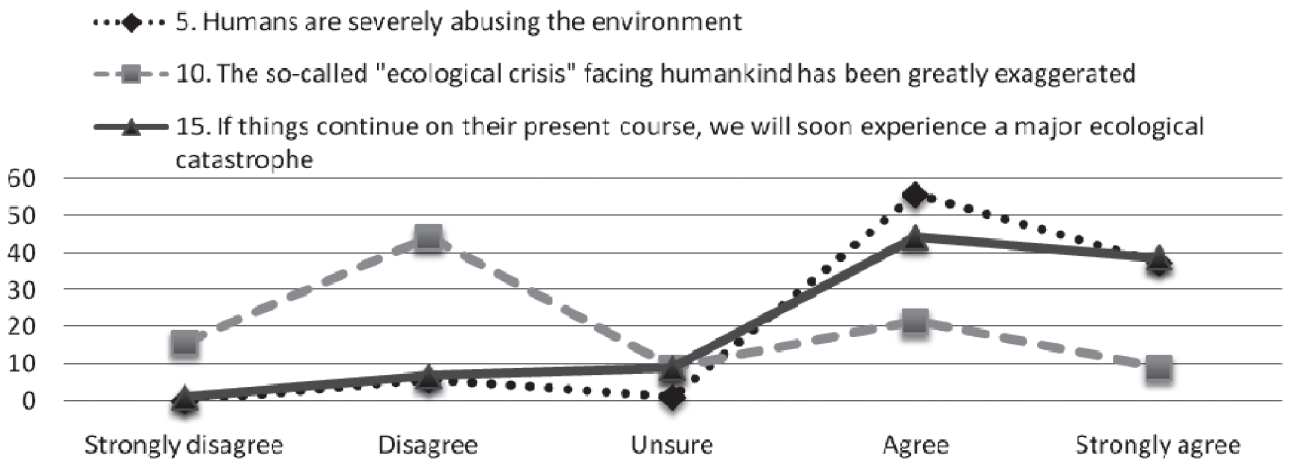

Figure 8. Attitudes of respondents about ecological crisis dimension (EC) statements: 5, 10 , and 15

On the proposition that humans are seriously abusing the environment (Item 5), $93.2 \%$ of respondents agreed, while $5.7 \%$ disagreed. Regarding item 15, the concern that continued abuse of the environment would yield an imminent ecological catastrophe, $82.9 \%$ of respondents agreed, $9.1 \%$ were uncertain, while only $8 \%$ disagreed. Overall, about $2 / 3$ of respondents believe that the ecological crisis is not something exaggerated by environmentalists, and almost all respondents are convinced that our abuse of nature is severe. Not unexpectedly, therefore, $82.9 \%$ of respondents concerned that without a change of existing course, an ecological catastrophe loomed.

\section{Conclusions}

This is the first effort to test public attitudes toward NEP scale in Kosovo, a country where the inherited environmental situation and environmental developments in the last decade were seen by $90 \%$ of the respondents as deteriorating, both at global and local levels. At a global level, respondents believed that there could be major improvements in the coming years. This may be related to the attention paid to global environmental developments in the last decade, such as Paris Accords, which were at the discussion stage when the survey was conducted. The importance of the global community (especially EU countries where large numbers of respondents' families have lived since the 1990s) has given to the environment through environmental conventions, global policy documents, and global conferences may be inspiring this optimism. In contrast to the global level, respondents expected a further deterioration of the environmental situation in Kosovo. This may reflect the fact that, since the end of wars of Yugoslav secession of the 1990s, Kosovo institutions have lacked environmental protection and sustainable development principles in their public policy agendas. There is too little sustainable investment in the environment. Kosovo is not yet party to any environmental convention that imposes requirements for better environmental performance. Environmental education, both formal and informal, is in its very initial stages after the new national curriculum is adopted. Despite the concerns of the teachers who were surveyed, environmental awareness by the public at large is still at quite a low level.

One of the most difficult questions in environmental philosophy is the debate between anthropocentric and eco-centric accounts of value. The teachers responding to 
this survey were probably the first ones in Kosovo to come into direct contact with NEP statements, so the results are original and largely supportive of the pro-NEP approach and eco-centric view. In statements related to the anti-exclusivity of humans, or human "anti-exclusion", most respondents hoped that human intelligence would avoid the risk of making the Earth uninhabitable and that this ingenuity would enable man to control nature endorsing anthropocentric view. Most respondents agreed that, despite this power of human intelligence, humankind would be still subjected to the laws of nature, showing eco-centric view.

In statements related to NEP's anti-anthropocentrism dimension, survey respondents almost completely agreed that plants and animals had the same rights to live as humans (strong eco-centric view). In contrast, half of respondents, nevertheless, believed that humankind was created to rule over nature, and that humans had the right to adapt nature to their own needs supporting anthropocentric view. Regarding the NEP dimension of the limits to growth and the anti-anthropocentrism, the vast majority thought that the land resources were sufficient, only we needed to know how to manage them; supporting the anthropocentric view. However, half of the respondents agreed that we had come close to the population capacity limit that the Earth could hold endorsing eco-centric view.

NEP statements about the balance of nature dimension and threat of human intervention in nature are supported by most of the teachers. Thus, the vast majority of respondents agreed that the balance of nature was subtle and vulnerable, and recognized the devastating consequences of human interference. Most respondents admitted that the balance of nature could not withstand the growing needs of modern industry. All three previous statements endorse eco-centric view of respondents. The NEP statement about the impending ecological crisis knocking on the doors of humanity was not seen as a "false alarm," but a reality with consequences that we face every day: climate change, hurricanes, droughts, floods, new environmentally caused health problems etc. The vast majority of teachers agreed that we were badly abusing the environment, and as a consequence we were headed toward an ecological disaster if this continued, strongly supporting eco-centric.

This is the first pilot test using NEP scale to measure environmental concerns among Kosovar in-service teachers. In the future, the survey sample needs to be expanded with other teaching staff in other levels (primary, low and high secondary level) where the number of teachers is 22,744 (MEST, 2018). Moreover, for further assessment of anthropocentric and eco-centric views, the NEP scale may be tested with teacher-students and other socio-economic groups to determine how other economic sectors of the country perceive NEP values and propositions, as well comparative studies with other countries of similar groups. 


\section{References}

Albrecht, D., Bultena, G., Hoiberg, E., \& Novak, P. (1982). The new environmental paradigm scale. Journal of Environmental Education, 13, 39-43.

Aydos, E. H., \& Yagci, E. (2015). Examination of the teacher candidates' environmental attitudes vis NEP scale in terms of different variables. Journal of Education in Science, Environment and Health, 1, 20-27.

Bechtel, R. B., Corral-Verdugo, V., Asai M., \& Riesie, A. G. (2006). A cross cultural study of belief structures in USA, Japan, Mexico, and Peru. International Journal of Psychology, 41, 145-151.

Bechtel, R. B., Corral-Verdugo, V. C., \& Pinheiro, J. Q. (1999). Environmental belief systems: United States, Brazil, and Mexico. Journal of Cross-Cultural Psychology, 30, 122-128.

Cordano, M., Welcomer, S. A., \& Scherer, R. F. (2003). An analysis of the predictive validity of the New Ecological Paradigm Scale. Journal of Environmental Education, $34,22-28$.

Duffy, R. (2010). Shadow players: Ecotourism development, corruption and state politics in Belize. Third World Quarterly, 21, 549-565.

Dunlap, R., Van Liere, K., Mertig, A. G., \& Jones, R. E. (2000). Measuring endorsement of the new ecological paradigm: A revised NEP scale. Journal of Sociology, 56, 425-442.

Dunlap, R. (1980). Paradigmatic changes in social science. American Behavioral Sciences, 24, 5-14.

Dunlap, R., \& Van Liere, K. (1978). The new environmental paradigm: A proposed measuring instrument and preliminary results. Journal of Environmental Education, 9, 10-19.

Edgell, C. R. M., \& Nowell, D. (1989). The new environmental paradigm scale: Wildlife and environmental beliefs in British Columbia. Society and Natural Resources, an International Journal, 2(1), 285-296.

Erdogan, N. (2009) Testing the new ecological paradigm scale: Turkish case. African Journal on Agricultural Research, 4(10), 1023-1031.

Fedosejeva, J., Boče, A., Romanova, M., Iliško, D., \& Ivanova, O. (2018). Education for Sustainable Development: The choice of pedagogical approaches and methods for the implementation of pedagogical tasks in the Anthropocene age. Journal of Teacher Education for Sustainability, 20(1), 157-179.

Figueroa, A. (2017). Economics of the Anthropocene age. Retrieved June 14, 2018, from https://books.google.lv/books? isbn=3319625845

Gooch, G. (1995). Environmental beliefs and attitudes in Sweden and the Baltic States. Environment and Behavior, 27, 513-539.

Harraway J., Broughton, F., Deaker, L., Jowett, T., \& Shephard, K. (2012). Exploring the use of the revised New Ecological Paradigm Scale (NEP) to monitor the development of students' ecological worldviews. The Journal of Environmental Education, 43(3), 177-191. doi: 10.1080/00958964.2011.634450

Johnson, C. Y., Bowker, J. M., \& Cordell, H. K. (2004). Ethnic variation in environmental belief and behavior: An examination of the New Ecological Paradigm in a social psychological context. Environment and Behavior, 36, 157-186.

Kress, J. W., \& Stine, J. K. (2017). Living in the Anthropocene: Earth in the Age of Humans. Washington: Smithsonian Institution Scholarly Press. 
Kortetmäki, T. (2013). Anthropocentrism versus eco-centrism revisited: Theoretical confusions and practical conclusions. SATS: Northern European Journal of Philosophy, 14(1), 21-37. doi: 10.1515/sats-2013-0002

La Trobe, H. L., \& Acott, T. G. (2000). Modified NEP/DSP environmental attitudes scale. Journal of Environmental Education, 32, 12-20.

Lalonde, R., \& Jackson, E. L. (2002). The new environmental paradigm scale: Has it outlived its usefulness? Journal of Environmental Education, 33, 28-36.

Leung, C., \& Rice, J. (2002). Comparison of Chinese-Australian and Anglo-Australian environmental attitudes and behavior. Social Behavior and Personality, 30, 251262.

Likert, R. (1932). A technique for the measurement of attitudes. Archives of Psychology, $140,1-55$.

Lindemann-Matthies, P., \& Hyseni, M. (2009). Perception of and knowledge about biodiversity by stakeholders and laypersons in Kosovo. Journal of International Environmental Application and Science, 4, 413-427.

Luzar, E. J., Diagne, C. G., \& Henning, B. R. (1995). Evaluating nature-based tourism using the New Environmental Paradigm. Journal of Agriculture and Applied Economy, $27(2), 544-555$.

Lück, M. (2003). The new environmental paradigm: Is the scale of Dunlap and Van Liere applicable in a tourism context? Tourism Geographies, 5, 228-240.

Manoli, C., Johnson, B., \& Dunlap, R. E. (2007). Validating the new ecological paradigm scale for use with children. Journal of Environmental Education, 38(4), 2-13.

MEST - Ministry of Education, Science and Technology. (2018). Statistics of education in Kosovo 2017/18. https://masht.rks-gov.net/uploads/2018/07/statistikat-e-arsimitne-kosove-2017-18.pdf. Accessed on November 29, 2018.

Milbrath, L. W. (1984). Environmentalists: Vanguard for a new society. Albany, NY: SUNY Press.

Millett, D. (2015). Anthropocene: The age of man. North Charleston: A DBA of On Demand Publishing LLC.

Noblet, C. L., Anderson, M., \& Teisl, M. F. (2013). An empirical test of anchoring the NEP scale in environmental ethics. Environmental Education Research, 19(4), 540551.

Noe, P. F., \& Snow, R. (1990). The new environmental paradigm and further scale analysis. Journal of Environmental Education, 21(4), 20-26.

Nooney, J. G., Woodrum, E., Hoban, T. J., \& Clifford, W. B. (2003). Environmental worldview and behavior: Consequences of dimensionality in a survey of North Carolinians. Environmental Behaviour, 35, 763-783.

Ozsoy, S. (2012). A survey of Turkish pre-service science teachers' attitudes toward the environment. Eurasian Journal of Educational Research, 46, 121-140.

Petegem, V. P., \& Blieck, A. (2006). The environmental worldview of children: A crosscultural perspective. Environmental Education Research, 12(5), 625-635.

Poortinga, W., Steg, L., \& Vlek, C. (2004). Values, environmental concern, and environmental behavior: A Study into Household Energy Use. Environmental Behavior, 36, 70-93.

Rideout, B. E., Hushen, K., McGinty, D., Perkins, S., \& Tate, J. (2005). Endorsement of the New Ecological Paradigm in systematic and email samples of university students. Journal of Environmental Education, 36, 15-23. 
Veselaj, Z., \& Torkar, G. (2016). The acceptability of teachers' value related statements about sustainable development and climate change among non-Science and science major students from Kosovo. European Journal of Sustainable Development, 6(1), 221-232.

Veselaj, Z., \& Mustafa, B. (2015). Overview of nature protection progress in Kosovo. Landscape Online, 45, 1-10. doi: 10.3097/LO.201545

Veselaj, Z., \& Krasniqi, Z. (2014). Mapping of education for sustainable development in the new curriculum of Kosovo and challenges of implementation. International Multidisciplinary Scientific Conference on Social Sciences and Arts SGEM2014, www.sgemsocial.org, SGEM2014 Conference Proceedings. September 1-9, 2014, Book 1, Vol. 1, 803-810.

Veselaj, Z. (2013). Environment. In Kosovo - a monographic survey (pp. 72-78). Prishtina: Academy of Sciences and Arts of Kosovo.

Vlek, C., \& Steg, L. (2007). Human behavior and environmental sustainability: Problems, driving forces, and research topics. Journal of Social Issues, 63, 1-19.

Correspondence concerning this paper should be addressed to Veselaj Zeqir, Associate Professor, Faculty of Education, University of Prishtina, Str. Agim Ramadani Nr.350, 10000 Prishtina, Republic of Kosovo. Email: Zeqir.veselaj@uni-pr.edu 